\title{
Topiramate effects lipolysis in 3T3-L1 adipocytes
}

\author{
GABRIELA POLTRONIERI CAMPAGNARO MARTINS ${ }^{1 *}$, CAMILA OLIVEIRA SOUZA ${ }^{2 *}$, \\ SCHEROLIN DE OLIVEIRA MARQUES ${ }^{1}$, THAIS FERNANDES LUCIANO ${ }^{1}$, BRUNO LUIZ DA SILVA PIERI ${ }^{1}$, \\ JOSÉ CÉSAR ROSA ${ }^{2}$, ADELINO SANCHEZ RAMOS DA SILVA ${ }^{3}$, JOSÉ RODRIGO PAULI ${ }^{4}$, \\ DENNYS ESPER CINTRA ${ }^{4}$, EDUARDO ROCHETE ROPELLE ${ }^{4}$, BRUNO RODRIGUES ${ }^{5}$, \\ FABIO SANTOS DE LIRA ${ }^{6}$ and CLAUDIO TEODORO DE SOUZA ${ }^{1}$
}

\begin{abstract}
${ }^{1}$ Laboratory of Exercise Biochemistry and Physiology, Health Sciences Unit, University of Extremo Sul Catarinense, Criciúma, SC 88806-000; ${ }^{2}$ Immunometabolism Research Group, Institute of Biomedical Sciences, University of Sao Paulo, São Paulo, SP 05508-900; ${ }^{3}$ School of Physical Education and Sport of Ribeirão Preto, University of São Paulo (USP), Ribeirão Preto, SP 14040-907; ${ }^{4}$ School of Applied Sciences, University of Campinas (UNICAMP), Limeira, SP 13484-350; 5 Laboratory of Human Movement, São Judas Tadeu University, São Paulo, SP 03166-000; ${ }^{6}$ Immunometabolism Research Group, Department of Physical Education, University Estadual Paulista (UNESP), Presidente Prudente, SP 19060-900, Brazil
\end{abstract}

Received July 15, 2015; Accepted August 4, 2015

DOI: $10.3892 /$ br.2015.514

\begin{abstract}
Studies have shown that topiramate (TPM)-induced weight loss can be dependent on the central nervous system (CNS). However, the direct action of TPM on adipose tissue has not been tested previously. Thus, the present study aimed to examine whether TPM modulates lipolysis in 3T3-L1. The 3T3-L1 cells were incubated in $50 \mu \mathrm{M}$ TPM for $30 \mathrm{~min}$. The $\beta$-adrenergic stimulator, isoproterenol, was used as a positive control. The release of lactate dehydrogenase, non-esterified fatty acid, glycerol and incorporation of ${ }^{14} \mathrm{C}$-palmitate to lipid were analyzed. The phosphorylation of protein kinase $\mathrm{A}$ (PKA), hormone-sensitive lipase (HSL), adipocyte triglyceride lipase (ATGL) and perilipin A, as well as the protein levels of comparative genetic identification 58 (CGI-58) were assessed. The levels of glycerol and non-esterified fatty acid increased markedly when the cells were treated with TPM. The TPM effects were similar to the isoproterenol positive control. Additionally, TPM reduced lipogenesis. These results were observed without any change in cell viability. Finally, the
\end{abstract}

Correspondence to: Dr Claudio Teodoro de Souza, Laboratory of Exercise Biochemistry and Physiology, Health Sciences Unit, University of Extremo Sul Catarinense, Criciúma, SC 88806-000, Brazil

E-mail: ctsouza@unesc.net

*Contributed equally

Abbreviations: ATGL, adipocyte triglyceride lipase; CGI-58, cofactor comparative genetic identification 58; CNS, central nervous system; HSL, hormone-sensitive lipase; LDH, lactate dehydrogenase; NEFA, non-esterified fatty acid; PKA, protein kinase A; TAG, triglycerides; TPM, topiramate

Key words: obesity, topiramate, 3T3-L1 adipocytes, lipolysis, weight loss phosphorylation of PKA, HSL, ATGL and perilipin A, as well as the protein levels of CGI-58 were increased compared to the control cells. These results were similar to those observed in the cells treated with isoproterenol. The present results show that TPM increased the phosphorylation of pivotal lipolytic enzymes, which induced lipolysis in 3T3-L1 adipocytes, suggesting that this drug may act directly in the adipose tissue independent from its effect on the CNS.

\section{Introduction}

Obesity is associated with several chronic diseases. Environmental changes are not sufficient to control obesity; however, there is overwhelming evidence that certain pharmacological agents may act as therapeutic targets for obesity. One such agent is topiramate (TPM), initially used for epilepsy treatment and migraine prophylaxis. TPM is a glutamate $\alpha$-amino-3-hydroxy-5-methyl-4-isoxazolepropionic acid/kainate receptor agonist and enhances the inhibitory effects mediated by $\gamma$-aminobutyric acid (1). One of the side effects of TPM is weight loss, which makes this drug a possible option for obesity treatment. The central mechanisms suggested for TPM-induced weight loss include a reduction in energy efficiency, influence on the hypothalamus and alteration of neuropeptides (1). However, the direct action of TPM on adipose tissue, particularly on lipolysis, has not been observed.

Two essential enzymes for lipid hydrolysis are adipocyte triglyceride lipase (ATGL) and hormone-sensitive lipase (HSL). ATGL hydrolyzes triacylglycerols into a fatty acid and a diacylglycerol (2). To fully activate, ATGL must interact with its cofactor, comparative genetic identification 58 (CGI-58) (3). In adipocytes without lipolytic stimuli, CGI-58 is strongly bound to lipid droplets, interacting with perilipin A (2). However, perilipin A and CGI-58 dissociate when lipolytic activity is stimulated by the activation of $\beta$-adrenergic receptors, which causes an increase in the cyclic adenosine monophosphate and consequent activation of protein kinase A (PKA). This 
process releases CGI-58 to associate with ATGL. Perilipin A is a structural protein that coats lipid droplets and protects triglycerides (TAG) molecules from basal enzymatic hydrolysis (4). Additionally, in stimulated cells, perilipin A is phosphorylated and facilitates the HSL translocation from the fat vesicles surface with consequent access to its diacylglycerol substrate (5). Together, the phosphorylation of HSL and its translocation to the lipid droplets surface, coupled with the activation of ATGL by CGI-58, results in the hydrolysis of $90 \%$ of TAG.

TPM treatment has been shown to reduce adiposity in humans and rodents $(6,7)$. TPM is assumed to act directly on lipolysis, however, this has not been explicitly described in vivo, once TPM acts on the central nervous system (CNS). Thus, in the present study, 3T3-L1 adipocytes were used and TPM was demonstrated to have a direct effect on lipolysis.

\section{Materials and methods}

Cell culture and measurement of lipolysis. 3T3-L1 cells were obtained from the American Type Culture Collection and cultured at $37^{\circ} \mathrm{C}$ in $5 \% \mathrm{CO}_{2}$ in Dulbecco's modified Eagle's medium supplemented with $25 \mathrm{mmol} / \mathrm{l}$ glucose, $1.0 \mathrm{mmol} / \mathrm{l}$ pyruvate, $4.02 \mathrm{mmol} / 1 \mathrm{~L}$-alanyl-glutamine and $10 \%$ fetal bovine serum (Gibco, New York, NY, USA). Cell differentiation began $24 \mathrm{~h}$ after confluency and occurred over 4 days in a medium containing $0.25 \mu \mathrm{M}$ dexamethasone, $0.5 \mathrm{mmol} / \mathrm{l}$ 3 -isobutyl-1-methylxanthine and $5 \mu \mathrm{g} / \mathrm{ml}$ insulin (Sigma, St. Louis, MO, USA). Following differentiation, the cells were cultured for 10 days in growth medium containing $5 \mu \mathrm{g} / \mathrm{ml}$ of insulin. Each parameter was evaluated using a 6-well aliquot from this culture. On day 10 after differentiation, the cells were incubated for $24 \mathrm{~h}$ in a medium containing $0.5 \%$ fetal bovine serum. Cells were treated with $10 \mu \mathrm{l}$ of TPM $(50 \mu \mathrm{M})$ or isoproterenol $(20 \mu \mathrm{M})$ for $30 \mathrm{~min}$. At the end of the incubation, the glycerol and non-esterified fatty acid (NEFA) contents (Wako Chemical, Richmond, Inc., VA, USA) of the incubation medium were used as an index of lipolysis and were measured using enzymatic-colorimetric kits. In addition, the release of lactate dehydrogenase (LDH) induced by plasma membrane disruption in culture medium was used as a cellular viability index.

Incorporation of $\left[1-{ }^{14} \mathrm{C}\right]$-palmitate into lipids. Cells were incubated in Krebs/Ringer/phosphate buffer ( $\mathrm{pH} 7.4$ ), supplemented with $1 \%$ bovine serum albumin and $1 \mathrm{mmol} / \mathrm{l}$ palmitate, at $37^{\circ} \mathrm{C}$ under a $\mathrm{CO}_{2}(5 \%) / \mathrm{O}_{2}(95 \%)$ gas mixture. Aliquots $(450 \mu \mathrm{l})$ were transferred to polypropylene test tubes containing $5 \mu \mathrm{l}$ of $\left[1-{ }^{14} \mathrm{C}\right]$-palmitate, in the presence or absence of insulin $(10 \mathrm{nmol} / \mathrm{l})$, and in the presence or absence of TPM $(50 \mu \mathrm{M})$. These samples were subsequently incubated for $1 \mathrm{~h}$ at $37^{\circ} \mathrm{C}$ in a water bath. Following incubation, the mixture was acidified with $0.2 \mathrm{ml} \mathrm{H}_{2} \mathrm{SO}_{4}(8 \mathrm{~N})$ and incubated for an additional $30 \mathrm{~min}$. At the end of the incubation, the reaction mixture was treated with $2.5 \mathrm{ml}$ of Dole's reagent (isopropanol: $n$-heptane: $\mathrm{H}_{2} \mathrm{SO}_{4}, 4: 1: 0.25, \mathrm{v} / \mathrm{v} / \mathrm{v}$ ) for lipid extraction.

Immunoblotting. The whole cell extracts were prepared by lysis of the cells in extraction buffer [1\% Triton X-100, $100 \mathrm{mmol} / \mathrm{l}$
Tris (pH 7.4), containing $100 \mathrm{mmol} / \mathrm{l}$ sodium pyrophosphate, $100 \mathrm{mmol} / 1$ sodium fluoride, $10 \mathrm{mmol} / 1$ EDTA, $10 \mathrm{mmol} / 1$ sodium vanadate, $2 \mathrm{mmol} / \mathrm{l}$ phenylmethylsulphonyl fluoride and $0.1 \mathrm{mg}$ of aprotinin $/ \mathrm{ml}]$ at $4^{\circ} \mathrm{C}$. The extracts were centrifuged at 9,000 x g at $4^{\circ} \mathrm{C}$ (5804R; Eppendorf AG, Hamburg, Germany) for $40 \mathrm{~min}$ to remove insoluble material, and the supernatants of these tissues were used for protein quantification, according to the Bradford method. Proteins were denatured by boiling in Laemmli sample buffer containing $100 \mathrm{mM}$ dithiothreitol, run on SDS-PAGE and transferred to nitrocellulose membranes. Membranes were blocked, probed and blotted with primary antibodies. Antibodies used for immunoblotting were phospho HSL ${ }^{\text {ser660 }}$, phospho HSL ${ }^{\text {ser563, }}$, HSL total (Cell Signaling Technology, Beverly, MA, USA), and phospho $\mathrm{PKA}^{\mathrm{Thr} 198}$, PKA total, CGI-58, perilipin A (Santa Cruz Biotechnology, Inc., Dallas, TX, USA), phospho ATGL $^{\text {Ser406 }}$, ATGL total, $\beta$-actin (Abcam, Eugene, OR, USA), and phospho perilipin A (Vala Sciences, Inc., San Diego, CA, USA). Chemiluminescent detection was performed with horseradish peroxidase-conjugated secondary antibodies (Thermo Scientific, Rockford, IL, USA). Autoradiographs of membranes were obtained for visualization of protein bands. The results of the blots are presented as direct comparisons of the area of the apparent bands in autoradiographs and quantified by densitometry using the Scion Image software (Scion Image software; Scion Corp., Frederick, MD, USA).

Statistical analysis. Bars represent 6 different experiments. Differences between the groups were evaluated using one-way analysis of variance followed by the Bonferroni post hoc test. $\mathrm{P}<0.05$ was considered to indicate a statistically significant difference. The software used for data analysis was the Statistical Package for the Social Sciences (SPSS) version 17.0 for Windows (SPSS, Inc., Chicago, IL, USA).

\section{Results}

Effects of TPM on lipolysis in 3T3-L1 adipocytes. To evaluate TPM-induced physiological alterations in lipolysis, the glycerol and NEFA contents were assayed in the incubation medium. The contents of glycerol and NEFA in isoproterenol-treated cells were higher compared with the control group. Similar results were observed for the isoproterenol group (Fig. 1A and B). To analyze lipogenesis, insulin-induced $\left[1-{ }^{14} \mathrm{C}\right]$-palmitate incorporation into lipids was assayed. These results show that the use of TPM decreased palmitate incorporation into lipids compared to the control group regardless of insulin stimulus (Fig. 1C). To evaluate whether TPM exposure effects cellular viability, the cytosolic enzyme LDH release was quantified. The analyzed groups did not demonstrate significant differences, suggesting that TPM was not cytotoxic for the times and dosages used (Fig. 1D).

Based on the current findings, we hypothesize that TPM treatment could increase the phosphorylation of the main lipolytic enzymes. Subsequently, the phosphorylation of $\mathrm{PKA}^{\mathrm{Thr} 198}$, $\mathrm{HSL}^{\mathrm{Ser} 660}$, HSL $^{\mathrm{Ser} 563}$, ATGL ${ }^{\mathrm{Ser} 406}$ and perilipin A, as well as the protein levels of CGI-58, PKA ${ }^{\text {Thr198 }}$, HSL ${ }^{\text {Ser660 }}$ HSL $^{\text {Ser563, }}$, ATGL $^{\mathrm{Ser} 406}$ and perilipin A were analyzed (Fig. 1E-J). TPM treatment led to a higher enzymatic phosphorylation compared to the control group. Therefore, this result may explain, at least 
A

B
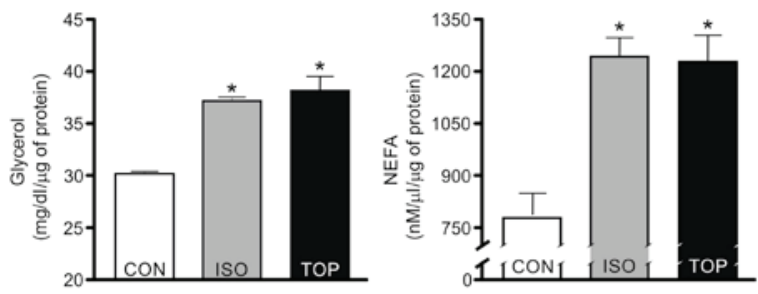

C

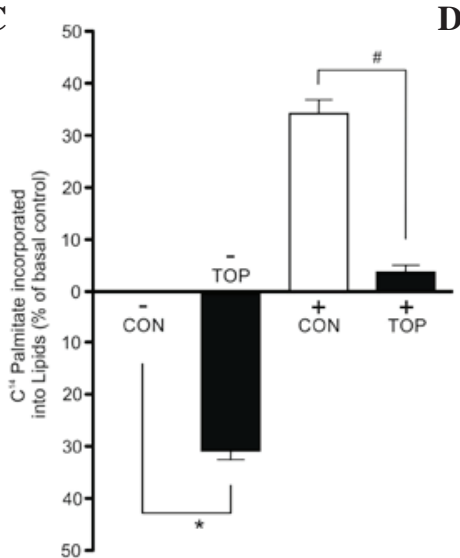

D
$\mathbf{E}$

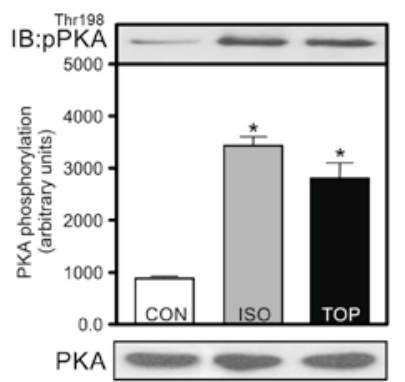

H

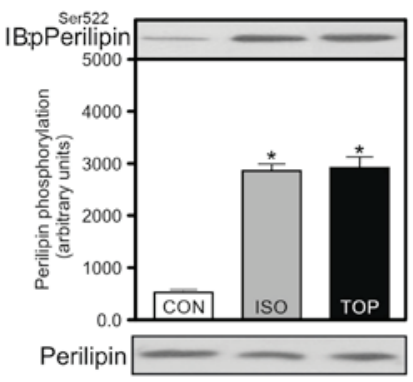

F

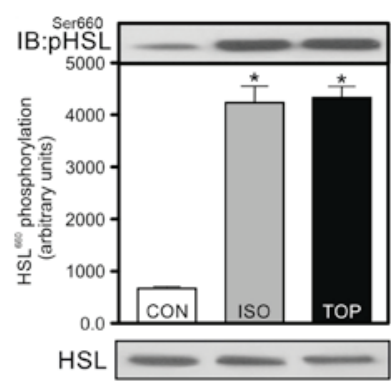

I

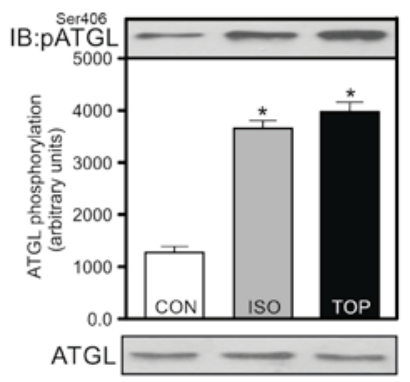

G

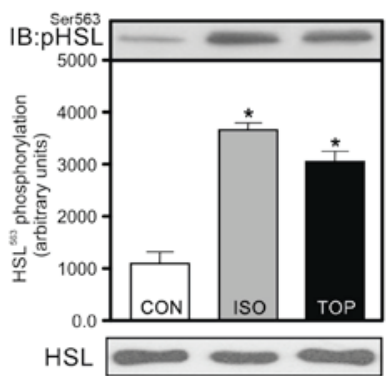

$\mathbf{J}_{18}$

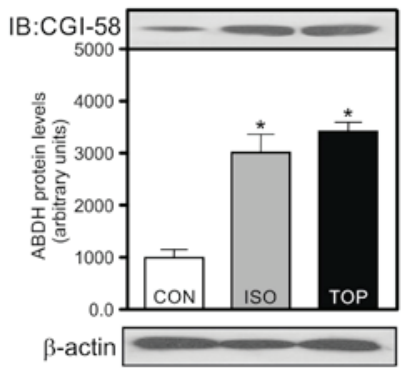

Figure 1. Effects of topiramate on the lipolysis and lipogenesis in 3T3-L1 adipocytes. Adipocytes were incubated for $30 \mathrm{~min}$ at $37^{\circ} \mathrm{C}$ in the presence or absence of topiramate or isoproterenol. (A) Release of glycerol and (B) non-esterified fatty acid (NEFA) into culture medium was measured and expressed as mg/dl $/ \mu \mathrm{g}$ of protein and $\mathrm{nM} / \mu \mathrm{l} / \mu \mathrm{g}$ of protein, respectively. Isoproterenol was the positive control. (C) The incorporation of $\left[{ }^{14} \mathrm{C}\right]$-palmitate into lipids in the presence or absence of insulin $(10 \mathrm{nmol} / \mathrm{l})$ and presence or absence of topiramate $(50 \mu \mathrm{M})$ was evaluated. The results are expressed as percentage of basal control. Cellular viability was evaluated by (D) monitoring lactate dehydrogenase (LDH) and expressed as $\mathrm{mmol} / \mathrm{l} / \mathrm{dl} / \mu \mathrm{g}$ of protein. Phosphorylation of (E) protein kinase A (PKA), (F) hormone-sensitive lipase ${ }^{\text {Ser660 }}\left(\mathrm{HSL}^{\text {Ser660 }}\right)$, (G) $\mathrm{HSL}^{\text {Ser563 }}$, (H) perilipin, (I) ATGL ${ }^{\text {Ser406 }}$ and (J) cofactor comparative genetic identification 58 (CGI-58) protein levels, respectively. The lower panel shows bands representative of PKA, HSL, perilipin, adipocyte triglyceride lipase (ATGL) and protein levels $\beta$-actin. Bars represent the mean \pm standard error of the mean of 6 different experiments. " $\mathrm{P}<0.05$, vs. control group. In Fig. $1 \mathrm{C}$, "P<0.05 vs. control group without insulin (-) and ${ }^{\#} \mathrm{P}<0.05$ for topiramate vs. control group with insulin (+). CON, control; ISO, isoproterenol; TOP, topiramate.

in part, why the glycerol and NEFA levels were increased. Notably, the analyzed protein phosphorylation and the CGI-58 protein levels were similar for cells treated with TPM or isoproterenol (Fig. 1E-J).

\section{Discussion}

As increased lipolysis and decreased lipogenesis cause fat loss in obese individuals, the present study tested whether the use of TPM increases lipolysis in 3T3-L1 cells. The 3T3-L1 cells treated with TPM presented high phosphorylation of lipolytic enzymes and subsequent lipolysis, without alteration of cell viability. In addition, the data showed that TPM modulated lipogenesis. A previous 6-month randomized human study indicated that TPM led to marked weight loss compared to the placebo (8). Another recent study showed that co-treatment with phentermine and TPM also induced weight loss in obese patients (9). A study in which animals were fed with a high fat diet showed that the concurrent TPM use at $50 \mathrm{mg} / \mathrm{kg}$ led to body weight reduction and insulin sensitivity improvement (10). Caricilli et al (11) observed that TPM improved insulin and leptin sensitivity in the hypothalamus of obese mice, which can contribute to the reduction of food intake and adiposity. However, these in vivo studies did not exclude the TPM effects on CNS.

In the present study, TPM treatment increased the release of NEFA and glycerol in the culture medium. In addition, decreased $\left[{ }^{14} \mathrm{C}\right]$-palmitate incorporation was observed in adipocytes exposed to TPM. One of the proposed mechanisms for lipogenesis reduction can be the carbonic anhydrase enzyme inhibition, which performs the first step of de novo lipogenesis. Although this enzyme was not analyzed in the present study, a previous study suggested that TPM can inhibit the cytosolic and mitochondrial levels of this enzyme, leading to weight loss (12). 
Subsequent to observing that NEFA and glycerol levels were changed, five molecules that have a crucial role in the triacylglycerol hydrolysis were analyzed. TPM treatment increased the phosphorylation of PKA, HSL, ATGL and perilipin A, as well as the protein levels of CGI-58 compared to control cells. However, the TPM-induced phosphorylation degrees were similar to those using isoproterenol. The present data did not allow the proposition of the mechanism responsible by the increase of these molecules induced by TPM. Taken together, these results demonstrate that TPM treatment led to lipolysis independently of its action on the CNS. These data increase the understanding of the processes involved on the TPM-induced weight loss and suggest a direct action of this drug on the adipose tissue.

\section{Acknowledgements}

The present study was supported by grants from Conselho Nacional de Desenvolvimento Científico e Tecnológico (CNPq) and University of Extremo Sul Catarinense (UNESC).

\section{References}

1. Verrotti A, Scaparrotta A, Agostinelli S, Di Pillo S, Chiarelli F and Grosso S: Topiramate-induced weight loss: A review. Epilepsy Res 95: 189-199, 2011.

2. Zechner R, Kienesberger PC, Haemmerle G, Zimmermann R and Lass A: Adipose triglyceride lipase and the lipolytic catabolism of cellular fat stores. J Lipid Res 50: 3-21, 2009.

3. Lass A, Zimmermann R, Haemmerle G, Riederer M, Schoiswohl G, Schweiger M, Kienesberger P, Strauss JG, Gorkiewicz G and Zechner R: Adipose triglyceride lipase-mediated lipolysis of cellular fat stores is activated by CGI-58 and defective in Chanarin-Dorfman Syndrome. Cell Metab 3: 309-319, 2006.
4. Sztalryd C, Xu G, Dorward H, Tansey JT, Contreras JA, Kimmel AR and Londos C: Perilipin A is essential for the translocation of hormone-sensitive lipase during lipolytic activation. J Cell Biol 161: 1093-1103, 2003.

5. Brasaemle DL: Thematic review series: Adipocyte biology. The perilipin family of structural lipid droplet proteins: Stabilization of lipid droplets and control of lipolysis. J Lipid Res 48: 2547-2559, 2007.

6. Ben-Menachem E, Axelsen M, Johanson EH, Stagge A and Smith U: Predictors of weight loss in adults with topiramate-treated epilepsy. Obes Res 11: 556-562, 2003.

7. Picard F, Deshaies Y, Lalonde J, Samson P and Richard D: Topiramate reduces energy and fat gains in lean $(\mathrm{Fa} /$ ? $)$ and obese (fa/fa) Zucker rats. Obes Res 8: 656-663, 2000.

8. Wilding J, Van Gaal L, Rissanen A, Vercruysse F and Fitchet M; OBES-002 Study Group: A randomized double-blind placebo-controlled study of the long-term efficacy and safety of topiramate in the treatment of obese subjects. Int J Obes Relat Metab Disord 28: 1399-1410, 2004.

9. Gadde KM, Allison DB, Ryan DH, Peterson CA, Troupin B, Schwiers ML and Day WW: Effects of low-dose, controlled-release, phentermine plus topiramate combination on weight and associated comorbidities in overweight and obese adults (CONQUER): A randomised, placebo-controlled, phase 3 trial. Lancet 377: 1341-1352, 2011.

10. Abo-Elmatty DM and Zaitone SA: Topiramate induces weight loss and improves insulin sensitivity in dietary obese rats: Comparison to sibutramine. Eur Rev Med Pharmacol Sci 15: 1187-1195, 2011.

11. Caricilli AM, Penteado E, de Abreu LL, Quaresma PG, Santos AC, Guadagnini D, Razolli D, Mittestainer FC, Carvalheira JB, Velloso LA, et al: Topiramate treatment improves hypothalamic insulin and leptin signaling and action and reduces obesity in mice. Endocrinology 153: 4401-4411, 2012.

12. Supuran CT, Di Fiore A and De Simone G: Carbonic anhydrase inhibitors as emerging drugs for the treatment of obesity. Expert Opin Emerg Drugs 13: 383-392, 2008. 